\title{
AMPHIBIAN FAUNA OF NAGALAND WITH NINETEEN NEW RECORDS FROM THE STATE INCLUDING FIVE NEW RECORDS FOR INDIA
}

\author{
J. Meren Ao ${ }^{1}$, Sabitry Bordoloi ${ }^{2}$ and Annemarie Ohler ${ }^{3}$ \\ ${ }^{1}$ Kohima Science College, Kohima, Nagaland, India. \\ ${ }_{2}^{2}$ Associate Professor, In-Charge,Resource Management and Environment Division, Institute of Advanced Study in Science and Technology \\ (IASST), Jawaharnagar, Khanapara, Guwahati, Assam 781022, India. \\ ${ }^{3}$ Departement de Systematique, UMS 0602, 25 rue Cuvier, 75005 Paris, France. \\ Email:2sabitrybordoloi@rediffmail.com;3ohler@mnhn.fr
}

\begin{abstract}
The amphibian fauna of Nagaland is updated to 32 species, 19 of which are new to the state and five species, Megophrys wuliangshanensis, Megophrys glandulosa, Amolops viridimaculatus, Rana humeralis and Rhacophorus gongshanensis, are new to India. The elements that compose this fauna are complex and include species from Himalayan region from northeastern montane region and also from the Indian subcontinent.
\end{abstract}

\section{Keywords}

Amolops viridimaculatus, Amphibia, India, Megophrys glandulosa, Megophrys wuliangshanensis, Nagaland, new records, new synonymy, Rana humeralis, Rhacophorus gongshanensis

\section{Introduction}

The Indian state of Nagaland lies between $25^{\circ} 15^{\prime}-27^{\circ} 04^{\prime} \mathrm{N}$ latitude and $93^{\circ} 20^{\prime}-95^{\circ} 15^{\prime} \mathrm{E}$ longitude. It is bordered on the north by Arunachal Pradesh, on the west by Assam, south by Manipur, north-east by Arunachal Pradesh and east by Myanmar. The area of the state is $16,527 \mathrm{~km}^{2}$. The state is hilly with wide deep gorges and steep terrain except narrow valleys. The mountain system is an offshoot of the Himalayan mountain system. The altitude varies between 110 and $3830 \mathrm{~m}$. The low mountain range runs from north to south along Assam-Nagaland border and is composed of rather low hills with altitude less than $1000 \mathrm{~m}$. A hill range with peaks higher than $1800 \mathrm{~m}$ with thick forest runs from north to south and divides the wetlands of Brahmaputra valley in India and the Chindwin wetlands in Myanmar. The Patkai mountain system with thick forest cover forms the international boundary between India and Myanmar. The highest peak of Patkai range is Saramati with a height of $3837 \mathrm{~m}$ above sea level.

The Barail mountain system with thick forest cover run in an east-west direction. The highest peak of this mountain system is Japfu which attains $3040 \mathrm{~m}$.

The climate of the state is subtropical but shows altitudinal zonation. The summer and winter temperatures vary from 0 to $29^{\circ} \mathrm{C}$ in hill areas and in the foot hills they vary from 12 to $36^{\circ} \mathrm{C}$. Saramati and its adjacent peaks receive snowfall in winter. Ground frosting is common in winter above an elevation of about $900 \mathrm{~m}$. The vegetation is tropical in lowland, subtropical above $1500 \mathrm{~m}$, temperate above $2500 \mathrm{~m}$ and subalpine above $3000 \mathrm{~m}$. The climatic condition is advantageous for high diversity of amphibians in the wetlands, swamps and other lotic and lentic habitats which abound all over Nagaland.

Most of the areas of Nagaland have remained unexplored for amphibian faunistic survey due to difficult hilly terrain. Kiyasetuo and Khare (1986) reported a new genus and species of frog from Nagaland, Pterorana khare. A year later, they reported on the presence of Rhacophorus bisacculus Taylor, 1962 in Nagaland (Kiyasetuo \& Khare, 1987). Chanda (1994) recorded 10 species of frogs from Nagaland. Kiyasetuo in his thesis (1986, unpublished) recorded 21 species from Kohima district. The present survey was carried out in different parts of Nagaland from 1998 to 2002.

The following list mentions the frogs collected during our survey from 1998 to 2002. Of the species recorded so far 19 species are new records from the state of which five are new records for India. The specimens have been deposited in the museum of 


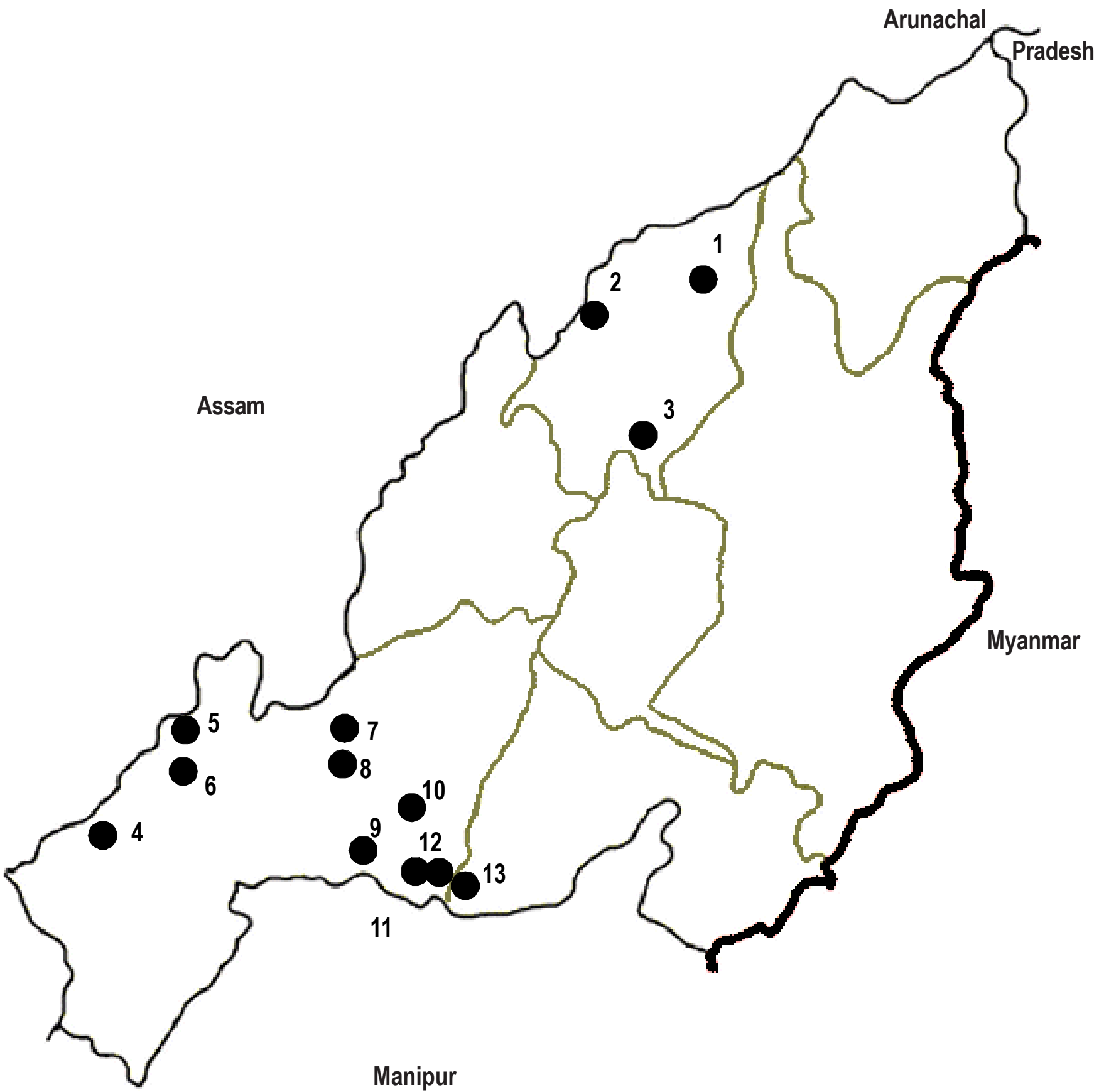

Figure 1. Map of Nagaland (India) showing places of collection of amphibians.

1 - Changtongyu (26 $\left.34^{\prime} \mathrm{N}, 9^{\circ} 41^{\prime} \mathrm{E}\right) ; 2$ - Tsurang $\left(2^{\circ} 32^{\prime} \mathrm{N}, 9^{\circ} 24^{\prime} \mathrm{E}\right)$, Watiyem $\left(26^{\circ} 30^{\prime} \mathrm{N}, 9^{\circ} 24^{\prime} \mathrm{E}\right) ; 3$ - Mokokchung;

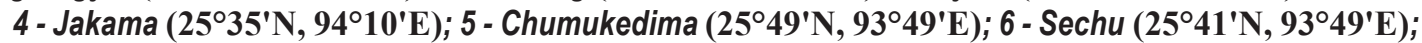

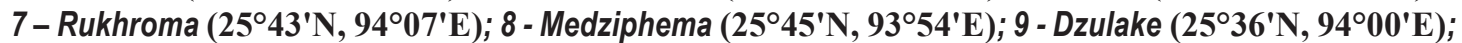
10 - Sanuru $\left(25^{\circ} 39^{\prime} \mathrm{N}, 9^{\circ} 06^{\prime} \mathrm{E}\right)$, Toulizie $\left(25^{\circ} 39^{\prime} \mathrm{N}, 9^{\circ} 06^{\prime} \mathrm{E}\right)$; 11 - Puliebadze $\left(25^{\circ} 37^{\prime} \mathrm{N}, 9^{\circ} 05^{\prime} \mathrm{E}\right)$;

12 - Dzuna ( $\left(25^{\circ} 37^{\prime} \mathrm{N}, 9^{\circ} 06^{\prime} \mathrm{E}\right)$; 13 - Itanki $\left(25^{\circ} 40^{\prime} \mathrm{N}, 9^{\circ} 31^{\prime} \mathrm{E}\right)$ 
the Kohima Science College, Kohima, Nagaland, India. The list gives their number in this collection (MA) and a few other specimens in other colections: Zoological Survey of India, Kolkata (ZSI), Muséum National d'Histoire Naturelle (MNHN).

For each species the valid name with its authority is given. Number and sex of specimens are listed with their collection number. For every locality of collection, altitude in meter above medium seal level is given. If available some data on ecology and habitat of the species in Nagaland are added. New taxonomic data are given in "Comments" section. The species are presented in alphabetical order of families, genera and species group names.

\section{BUFONIDAE Gray, 1825}

Bufo melanostictus Schneider, 1799

Materials examined

Six females, four males, MA 36-45.

\section{Morphological characters}

Large-sized frog (males SVL72.0-81.0mm, females SVL 95.0$112.0 \mathrm{~mm}$ ), parotoid glands and cranial ridges present, dorsal skin rough with numerous warts bearing horny spinules; tips of fingers and toes rounded, webbing moderate; dorsal color black brown or yellow brown with dark brown lines on crest, ventrally creamy yellow.

\section{Distribution}

All South and Southeast Asia.

\section{$\underline{\text { Remarks }}$}

Commonly present in the localities up to $2440 \mathrm{~m}$. Found in a variety of terrestrial habitats, including vicinity of human settlements.

\section{HYLIDAE Rafinesque, 1815}

\author{
Hyla annectans (Jerdon, 1870) \\ Materials examined

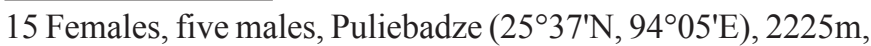 \\ MA 46-65.
}

\section{Morphlogical characters}

Small-sized frog (male SVL 31-41 mm, females SVL 41-49mm), smooth dorsal skin, fingers and toes with toepads, webbing moderate, dorsal color uniformely green with a dark line from tip of snout, canthus rostralis, tympanic fold to groin.

\section{Distribution}

Southern Asia (south of Himalaya) from Assam and Meghalaya
(India) through northern Myanmar, Thailand, and Vietnam to western China.

\section{$\underline{\text { Remarks }}$}

Arboreal in the post breeding season. Breeding in ponds and other water bodies. This species has been first described from Khasi Hills, Meghalaya, and shows a large distribution including Burma, Thailand, Vietnam and China. In China up to five subspecies are recognised. Hyla annectans is a species that seems to be limited to higher altitudes, particularly in the southern parts of its distribution. In Nagaland it can be observed above $1400 \mathrm{~m}$.

\section{MEGOPHRYIDAE Bonaparte, 1850}

\author{
Megophrys glandulosa (Boulenger, 1890) \\ Materials examined

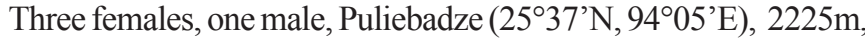
MA 22-25.

\section{Morphological characters}

Large-sized frog (males SVL 70-75mm, females SVL 74-82mm), dorsal skin smooth with fine ridges, laterally numerous glandular warts, a posteriorly thickened supratympanic fold; tips of fingers and toes rounded, rudimentary webs; dorsal color brown or gray brown, a brown black triangular spot between eyes, upper lip margin with a light colored longitudinal stripe, tubercles on flanks half black and half yellow; black spots on both sides of throat, posterior belly and ventral thighs with many dark colored spots.

Distribution

China (Yunan) and India (Nagaland).

\section{$\underline{\text { Remarks }}$}

New record for India. Forest floor dwelling, found near streams among bushes and shrubs.

\section{Megophrys major (Boulenger, 1908) \\ Materials examined \\ One female, one male, Dzuna (253 $\left.37^{\prime} \mathrm{N}, 9^{\circ} 06^{\prime} \mathrm{E}\right), 1980 \mathrm{~m}$, MA 20-21.}

\section{Morphological characters}

Large-sized frog (males SVL 68-75mm, females SVL 80-92mm), dorsal skin smooth with fine foldings and small tubercles, large tubercles on flanks, posterior part of supratympanic fold not enlarged; tips of fingers and toes rounded; rudimentary webs; dorsal color olive green or dark green, a dark brown triangular spot between eyes, upper lip margin with a light colored stripe, dorsum with a "Y"-shaped spot; some thin dark stripes on throat; belly and ventral thighs without spots. 
Distribution

China, India, Laos, Myanmar, Thailand, Vietnam.

\section{Remarks}

Forest floor dwelling, found near stream among the bushes, shrubs and leaf litters. New record for Nagaland. The specimens show the typical band on the upper lip. We use the name Megophrys major, as Ixalus lateralis Anderson, 1871 should apply to a member of the genus Leptolalax Dubois, 1980 (Dubois et al., in prep.).

\section{Megophrys wuliangshanensis Ye \& Fei, 1995 \\ Materials examined \\ Eight females, two males, Puliebadze $\left(25^{\circ} 37^{\prime} \mathrm{N}, 9^{\circ} 05^{\prime} \mathrm{E}\right), 2225 \mathrm{~m}$ \\ and Noklak $\left(26^{\circ} 03^{\prime} \mathrm{N}, 95^{\circ} 04^{\prime} \mathrm{E}\right), 1524 \mathrm{~m}, \mathrm{MA} 26-35$.}

\section{Morphological characters}

Small-sized frog (males SVL 27-32mm, females SVL 41-42mm), dorsum densely covered with granules, these granules forming ridges; large tubercles on lateral body, tips of fingers and toes rounded, webbing absent, dorsal color red brown or light red brown, a dark brown triangular spot between eyes and a Xshaped spot on back, longitudinally running dark stripes on lateral body, belly and ventral legs with round dark brown spots.

Distribution

China (Yunnan) and India (Nagaland).

\section{$\underline{\text { Remarks }}$}

New record for India. Forest floor dwelling, on rainy days observed in the daytime also.

\section{MICROHYLIDAE Günther, 1858}

\author{
Microhyla ornata (Duméril \& Bibron, 1841) \\ Materials examined \\ Six females, five males, Chumukedima $\left(25^{\circ} 49^{\prime} \mathrm{N}, 93^{\circ} 49^{\prime} \mathrm{E}\right), 250 \mathrm{~m}$; \\ Kohima (253’N, 9402’E), 1444 m, MA 66-76.
}

\section{Morphological characters}

Small-sized frog (males SVL 23-27mm, females SVL 23-28mm), dorsal skin smooth, tips of fingers and toes pointed, rudimentary web, dorsum with fine lines in divers brown and greyish tones forming triangular pattern, side of head and flanks dark brown.

\section{Distribution}

Common all over oriental region.

$\underline{\text { Remarks }}$

Found under leaf litter and crevices in paddy fields.

\section{RANIDAE Rafinesque-Schmaltz, 1814}

\section{Amolops gerbillus (Annandale, 1912) \\ Materials examined}

Two females, one male, Dzuna $\left(25^{\circ} 37^{\prime} \mathrm{N}, 9^{\circ} 06^{\prime} \mathrm{E}\right), 1700 \mathrm{~m}, \mathrm{MA}$ 89-91.

\section{Morphological characters}

Moderate-sized frog (male SVL 72-76mm, females SVL 82-87mm), dorsal skin shagreened, tips of fingers and toes with large discs, webbing large, dorsal colour grey with brown marbling, ventral body yellowish.

Distribution

China, India.

Remarks

New record for Nagaland. Torrent living frogs.

\section{Amolops marmoratus (Blyth, 1855)}

Materials examined

Eight females, four males, Jakama $\left(25^{\circ} 35^{\prime} \mathrm{N}, 94^{\circ} 10^{\prime} \mathrm{E}\right), 1600 \mathrm{~m}$, Tsurong (2632’ $\left.\mathrm{N}, 9^{\circ} 24^{\prime} \mathrm{E}\right), 914 \mathrm{~m}, \mathrm{MA} 77-88$.

\section{Morphological characters}

Moderate-sized frog (males SVL 57-63mm, females SVL 72$93 \mathrm{~mm}$ ), dorsal skin smooth, tips of fingers and toes with discs, webbing complete, dorsal color greenish (in life) with brown spots, legs with distinct bands, ventral side pearly white.

\section{Distribution}

China, India, Nepal, Thailand.

$\underline{\text { Remarks }}$

Torrent living, in streams with rocky bottom and boulders.

\author{
Amolops monticola (Anderson, 1871) \\ Materials examined

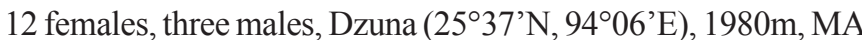 \\ 100-114.
}

\section{Morphological characters}

Small-sized frog (males SVL 38-47mm, females SVL 58-66mm), dorsal skin smooth with dorsolateral folds, tips of fingers and toes with discs, webbing complete, dorsal color variable from dark brown to light pale yellow, scattered with irregular brown markings, legs with crossbars, belly without spots.

Distribution

China, India, Nepal.

$\underline{\text { Remarks }}$

New record for Nagaland. Torrent living frogs. 


\section{Amolops viridimaculatus (Jiang, 1983)}

Materials examined

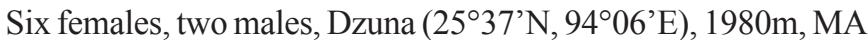
92-99.

\section{Morphological characters}

Large-sized frog (males SVL 73-82mm, females SVL 83-94mm), dorsal skin smooth, flanks with tubercles, tips of fingers and toes with discs, webbing complete, dorsal color flanks brown with large, large green spots, in between them scattered small green spots, legs with green crossbars.

Distribution

China (Yunnan), India (Nagaland).

$\underline{\text { Remarks }}$

New record for Nagaland. In streams with rocky bottom.

\section{Chirixalus vittatus (Boulenger, 1887)}

Materials examined

Four females, two males, Sanuru $\left(25^{\circ} 39^{\prime} \mathrm{N}, 9^{\circ} 06^{\prime} \mathrm{E}\right), 1410 \mathrm{~m}$,; Sechu $\left(25^{\circ} 41^{\prime} \mathrm{N}, 93^{\circ} 49^{\prime} \mathrm{E}\right), 1000 \mathrm{~m}, \mathrm{MA} 262-267$.

\section{Morphological characters}

Small-sized frog (males SVL 23-26mm, females SVL 24-27mm), dorsal skin smooth, tips of fingers and toes with small discs, webbing moderate, dorsal color yellow with evenly scattered with gray brown dots; a light yellow or cream white longitudinal stripe on each side of body from eye to groin.

\section{Distribution}

China, India, Myanmar, Thailand, Vietnam.

\section{$\underline{\text { Remarks }}$}

Observed on bushes, in holes in trees and bamboo internodes.

\section{Euphlyctis cyanophlyctis Schneider, 1799}

Materials examined

10 Females, six males, MA 162-177

\section{Morphological characters}

Moderate-sized frog (males SVL 38-66mm, females SVL 45$92 \mathrm{~mm}$ ), dorsal skin finely granular, tips of fingers and toes pointed, webbing complete, dorsal color greyish olive above, with dark olive spots; a dark light-edged band along each flank; lower parts white or vermiculate.

\section{Distribution}

Afghanistan, Bangladesh, India, Iran, Nepal, Pakistan, Sri Lanka.
Fejervarya teraiensis (Dubois, 1984)

Materials examined

12 females, five males, MA 181-197.

Morphological characters

Rather small-sized frog (males SVL 43-51 mm, females SVL 49-

$56 \mathrm{~mm}$ ), dorsal skin with fine glandular folds, tips of fingers and toes pointed, webbing moderate, dorsal color greyish with darker spots, middorsal line or band .

Distribution

India, Nepal.

$\underline{\text { Remarks }}$

New record for Nagaland. Widely distributed up to $2440 \mathrm{~m}$. Terrestrial, breeding in small ponds and ditches.

Fejervarya nepalensis (Dubois, 1975)

Materials examined

Eight females, four males, MA 198-209.

Morphological characters

Rather small-sized frog (males SVL 27-32mm, females SVL 32$40 \mathrm{~mm}$ ), dorsal skin with fine glandular folds, tips of fingers and toes pointed, webbing moderate, dorsal color greyish with darker spots and a middorsal line or band.

\section{Distribution}

India, Nepal.

\section{$\underline{\text { Remarks }}$}

New record for Nagaland. Widely distributed. Aquatic.

\section{Hoplobatrachus crassus Jerdon, 1853}

Materials examined

Nine females, two males, Itanki $\left(25^{\circ} 40^{\prime} \mathrm{N}, 93^{\circ} 31^{\prime} \mathrm{E}\right), 200 \mathrm{~m}, \mathrm{MA}$ 139-149.

\section{Morphological characters}

Large-sized frog (males SVL76-90mm, females SVL 82-112mm), dorsal skin with longitudinal glandular folds, tips of fingers and toes pointed, webbing large, dorsal color yellowish to olive with dark spots, middorsal line absent.

Distribution

India, Nepal, Sri Lanka.

$\underline{\text { Remarks }}$

New record for Nagaland. Semiaquatic.

$\underline{\text { Remarks }}$

Widely distributed up to $2440 \mathrm{~m}$. Aquatic. 


\section{Hoplobatrachus tigerinus Daudin, 1803}

Materials examined

Eight females, four males, Medziphema $\left(25^{\circ} 45^{\prime} \mathrm{N}, 93^{\circ} 54^{\prime} \mathrm{E}\right), 304 \mathrm{~m}$; Mankolemba $\left(26^{\circ} 31^{\prime} \mathrm{N}, 94^{\circ} 26^{\prime} \mathrm{E}\right), 914 \mathrm{~m}, \mathrm{MA} 150-161$.

\section{Morphological characters}

Large-sized frog (males SVL 77-108mm, females SVL 86-162mm), dorsal skin with longitudinal glandular folds, tips of fingers and toes pointed, webbing large to complete, dorsal color yellowish to olive with dark spots, middorsal line present.

\section{Distribution}

India, Nepal, Sri Lanka.

\section{Paa mokokchungensis (Das \& Chanda, 2000)}

Materials examined

Two males, ZSI A8889, Mokokchung, 1200m. Stream dewelling species. So far this species has been recorded only from this locality in Nagaland.

\section{Morphological characters}

Large-sized frog (males SVL 87mm), dorsal skin with glandular tubercles, tips of fingers and toes swollen, webbing large, dorsal color dark brown.

\section{Distribution}

India (Nagaland).

\section{Philautus annandalii (Boulenger, 1906)}

Materials examined

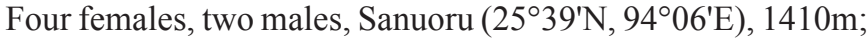

Khonoma $\left(25^{\circ} 37^{\prime} \mathrm{N}, 94^{\circ} 02^{\prime} \mathrm{E}\right), 1800 \mathrm{~m}, \mathrm{MA} 268-273$.

\section{Morphological characters}

Very small-sized frog (males SVL 17-20mm, females SVL 22$26 \mathrm{~mm}$ ), dorsal skin smooth, tips of fingers and toes with discs, webbed at base, dorsal color greyish olive with a bar between eyes and a dark curved band on each side of back.

\section{Distribution}

India, Nepal.

$\underline{\text { Remarks }}$

On bushes, can be found in day time also.

\section{Philautus garo (Boulenger, 1919)}

Materials examined

Two males, Dzulake (2536'N, 94º0'E), 1791m, MA274-275.

\section{Morphological characters}

Very small-sized frog (males SVL 22-23mm), dorsal skin smooth, tips of fingers and toes with discs, webbed at base, dorsal color grey with dark brown hourglass-shaped blotch.
Distribution

India (Meghalaya, Nagaland).

$\underline{\text { Remarks }}$

New record for Nagaland. Arboreal, in moist forest.

\section{Phrynoglosus borealis (Annandale, 1912)}

Materials examined

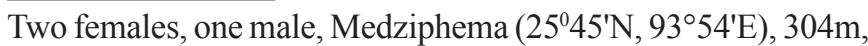
MA 178-180.

\section{Morphological characters}

Small-sized frog (male SVL 28mm, females SVL 30-38mm), dorsal skin with small glandular warts, tips of fingers and toes rounded, webbing large, dorsal color greyish brown.

Distribution

Bhutan, India.

$\underline{\text { Remarks }}$

New record for Nagaland. Found half buried in sand near streams, under stones near water fall etc.

\section{Polypedates megacephalus Hallowell, 1861}

Materials examined

Three females, two males, Watiyem $\left(26^{\circ} 30^{\prime} \mathrm{N}, 9^{\circ} 24^{\prime} \mathrm{E}\right), 300 \mathrm{~m}$, MA 257-261.

Morphological characters

Moderately-sized frog (males SVL 41-48mm, females SVL 57$65 \mathrm{~mm}$ ), dorsal skin smooth, no co-ossified skin on head, tips of fingers and toes with large discs, webbing moderate, dorsal color light brown with triangular spot between eyes and dots on back.

\section{Distribution}

China, India, Nepal.

$\underline{\text { Remarks }}$

New record for Nagaland. In undisturbed forest areas.

\section{Polypedates teraiensis (Dubois, 1987) \\ Materials examined \\ 10 females, eight males, Medziphema (25 45'N, 935''), 304m; Kohima, 1444m, MA 239-256. \\ Morphological characters \\ Large-sized frog (males SVL 52-63mm, females SVL 70-84mm), dorsal skin smooth with co-ossified skin of head, tips of fingers and toes with large discs, webbing moderate, dorsal color light brown with longitudinal brown lines.}




\section{Distribution}

India (Arunachal Pradesh, Nagaland), Myanmar, Nepal.

\section{$\underline{\text { Remarks }}$}

New record for Nagaland. Found in variety of terrestrial habitats, including vicinity of human settlements.

\section{Rana garoensis Boulenger, 1920}

Materials examined

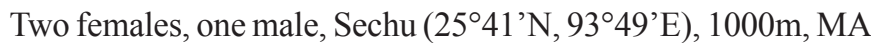
122-124.

\section{Morphological characters}

Moderate-sized frog (males SVL 35-48mm, females SVL 50$58 \mathrm{~mm}$ ), dorsal skin finely granular with dorsolateral folds, tips of fingers and toes with small discs, large web, dorsal color brown with irregularly set darker dots, lateral body dark brown.

\section{Distribution}

India, Nepal.

\section{$\underline{\text { Remarks }}$}

New record for Nagaland. Forest dwellers, found near streams where they breed. Study of the syntypes of Rana garoensis Boulenger, 1920 (ZSI 18557, 2 specimens) and the holotype of Rana danieli Pillai and Chanda, 1977 (ZSI A6966) showed that these two names are synonymes. The back is finely granular in both forms, like in Rana leptoglossa, but not showing the distinct colour pattern formed by regularly positioned round dark brown spots. The webbing of both Rana garoensis and Rana danieli is similar and only leaves two phalanges free on finger two. The valid name of the species is therefore Rana garoensis Boulenger, 1920.

\section{Rana humeralis Boulenger, 1887}

Materials examined

One female, one male, Tsurong $\left(26^{\circ} 30^{\prime} \mathrm{N}, 9^{\circ} 24^{\prime} \mathrm{E}\right), 305 \mathrm{~m}$, MA 120-121.

\section{Morphological characters}

Large-sized frog (males SVL 54-71 mm, female SVL 82mm), dorsal skin granular with narrow laterodorsal folds, in males prominent humeral glands, tips of fingers and toes with small disks, webbing large, dorsal color brown with small black spots, flanks brown, upper lip whitish.

\section{Distribution}

India (Assam, Nagaland), Myanmar, Nepal.

Remarks

New record for India. Inhabit swampy areas of low lands.

\author{
Rana khare (Kiyasetuo \& Khare, 1986) \\ Materials examined \\ Three males, Rukhroma $\left(25^{\circ} 43^{\prime} \mathrm{N}, 9^{\circ} 07^{\prime} \mathrm{E}\right), 1440 \mathrm{~m}$; Jokhoma, \\ 1600m, MA 115-117.
}

\section{Morphological characters}

Rather large-sized frog (males SVL 50-59mm), dorsal skin smooth with dorsolateral folds and loose skin folds on flanks, tips of fingers and toes with moderate discs, webbing large, dorsal color dark brown, belly white.

\section{Distribution}

India (Nagaland).

\section{$\underline{\text { Remarks }}$}

Semiaquatic. This frogs show loose skin similar to that found in males of some Brown frogs (Rana temporaria group) of Europe and Japan in breeding season. This skin flap probably facilitates breathing under water and may be linked to nest keeping behavior of the males. This is consistent with the observation of males staying under water near the clutches in mountain streams.

\section{Rana livida (Blyth, 1855)}

Materials examined

Four females, two males, Sechu $\left(25^{\circ} 41^{\prime} \mathrm{N}, 93^{\circ} 49^{\prime} \mathrm{E}\right), 1000 \mathrm{~m}, \mathrm{MA}$ 125-130.

\section{Morphological characters}

Large sexual dimorphism, males moderate-, females large-sized (males SVL 43-51mm, females SVL 85-95mm), dorsal skin smooth with indistinct dorsolateral folds, tips of fingers and toes with moderate discs, webbing large, dorsal color green with few dark rounded spots, lateral body and legs brown.

\section{Distribution}

China, India, Laos, Myanmar, Thailand, Vietnam.

Remarks

New record for Nagaland. Living in water falls, streams and similar habitats.

\section{Rana mawphlangensis Pillai \& Chanda, 1977}

Materials examined

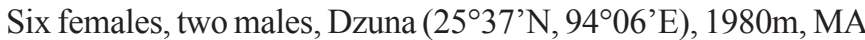
131-138.

\section{Morphological characters}

Large-sized frog (male SVL 80mm, females SVL 96-106mm), dorsal skin with distinct glandular warts and horny spinules, tips of fingers and toes moderately enlarged with discs, webbing moderate, dorsal color browish with bluish brown (green in life) spots and whitish horny spinules, throat and chest dark brown. 
Distribution

India (Meghalaya, Nagaland, West Bengal, Manipur).

\section{$\underline{\text { Remarks }}$}

New record for Nagaland. Near streams, semiaquatic. Rana mawphlangensis is a member of the subgenus Odorrana Fei, Ye \& Huang, 1990, and is morphologically close to the Rana (Odorrana) andersonii species group.

\section{Rana tytleri (Theobald, 1868)}

Materials examined

Two females, Watiyem $\left(26^{\circ} 30^{\prime} \mathrm{N}, 94^{\circ} 24^{\prime} \mathrm{E}\right), 300 \mathrm{~m}$, MA $118-119$.

Morphological characters

Rather small-sized frog (males SVL 28-32mm, females SVL 42mm), dorsal skin smooth with dorsolateral folds, tips of fingers and toes with small discs, webbing moderate, dorsal color bluish (green in life) with wide whitish lateral bands, black longitudinal stripes on hindlegs.

\section{Remarks}

New record for Nagaland. Found in swampy areas. Ohler \& Mallik (2002) showed that the frogs of the Rana (Hylarana) subgenus (sensu Dubois, 1992) from northeastern India are distinct both from Rana erythraea (Schlegel, 1837) and from Rana taipehensis van Denburgh, 1909. These frogs should be called Rana tytleri.

\section{Rhacophorus bipunctatus Ahl, 1927}

Materials examined

Three females, two males, Puliebadze $\left(25^{\circ} 37^{\prime} \mathrm{N}, 94^{\circ} 05^{\prime} \mathrm{E}\right), 2225 \mathrm{~m}$, MA 220-224.

\section{Distribution}

China, India, Malaysia, Myanmar, Thailand

\section{Morphological characters}

Rather small-sized frog (males SVL 32-39mm, females SVL 49$53 \mathrm{~mm}$ ), dorsal skin smooth, tips of fingers and toes with large discs, webbing complete; dorsal color brown or yellow, with dark brown X-shaped marking, posterior back with dark transverse stripes; flanks brightly yellow; legs with dark crossbars, toe web red.

\section{$\underline{\text { Remarks }}$}

New record for Nagaland. Arboreal, found in thick forests, mostly on trees.

\section{Rhacophorus gongshanensis (Yang \& Su, 1984)}

Materials examined

Seven females, four males, Puliebadze ( $\left.25^{\circ} 37^{\prime} \mathrm{N}, 9^{\circ} 05^{\prime} \mathrm{E}\right), 2225 \mathrm{~m}$, MA 225-235.

\section{Morphological characters}

Moderately-sized frog (males SVL 54-72mm, females SVL 66$82 \mathrm{~mm}$ ), dorsal skin granular, tips of fingers and toes with large discs, webbing complete; dorsal color grass green, covered with sparse brown spots; lateral body and anterior and posterior sides of thigh with large and small cream yellow spots.

Distribution

China (Yunnan), India (Nagaland).

$\underline{\text { Remarks }}$

New record for India. Arboreal, thick forest areas.

\section{Rhacophorus maximus Günther, 1858}

Materials examined

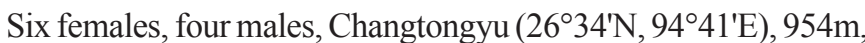
MA 210-219.

\section{Morphological characters}

Large-sized frog (males SVL 62-80mm, female SVL 85-110mm), dorsal skin smooth, tips of fingers and toes with large discs, webbing complete, dorsal color bluish (green in life) with blackish webbing.

Distribution

China, India, Nepal, Thailand.

$\underline{\text { Remarks }}$

New record for Nagaland. Found in thick forest area, both nocturnal and diurnal.

\section{Theloderma asperum (Boulenger, 1886)}

Materials examined

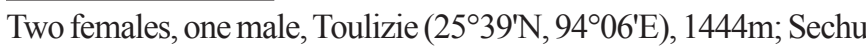
$\left(25^{\circ} 41^{\prime} \mathrm{N}, 93^{\circ} 49^{\prime} \mathrm{E}\right), 1000 \mathrm{~m}, \mathrm{MA} 236-238$.

\section{Morphological characters}

Small-sized frog (male SVL 30mm, females SVL 30-31mm), dorsal skin granular forming network-like ridges, tips of fingers and toes with discs, webbing moderate, anterior part of dorsum grey with brown spot between eyes, posterior par dark brown, greyish spots near vent which is dark brown.

Distribution

China, India (Assam, Nagaland), Malaysia, Myanmar, Thailand, Vietnam. 


\section{$\underline{\text { Remarks }}$}

New record for Nagaland. Found in stumps of bamboo internodes and holes in trees.

\section{Discussion}

The species listed by Chanda (1994) can be separated in four different biogeographic elements. The first group mainly includes species or names that cover species groups with large distributions, like Rana limnocharis (here as Fejervarya teraiensis and $F$. nepalensis), Polypedates leucomystax (here P. megacephalus and P. teraiensis) and Bufo melanostictus. A second group of species has its distribution area in the Indian subcontinent and reaches its easternmost range in Nagaland and western Myanmar, like Hoplobatrachus tigerinus or Euphlyctis cyanophlyctis. Some species (Hyla annectans, Rhacophorus bimaculatus, Rhacophorus maximus) can be considered to be elements of the northeastern montane region as defined by Inger (1999: 451) and Rana khare is an endemic form only known from Nagaland.

Our list adds 21 species to the fauna as published by Chanda (1994), five are new to India. It confirms close relationship of the amphibian fauna of Nagaland with that of northeastern region, but a link to the fauna from the Himalaya can be shown by the presence of species like Phrynoglossus borealis, Fejervarya nepalensis and Philautus annandalii, Rhacophorus maximus, Megophrys major and Amolops monticola. Some of the species found in Nagaland were first described from China (Rhacophorus gongshanensis, Amolops viridimaculatus) and are currently not known from inbetween localities, most probably because of lack of exploration.

The number of endemics might be higher after thorough revision of some groups, but the lack of data on the northeastern Indian region and on Myanmar does not allow such work currently. A series of taxonomic questions should be resolved. Kiyasetuo and Khare (1987) reported on the presence of Rhacophorus bisacculus Taylor, 1962 in Nagaland. This species has been described from central Thailand and is a member of a group of treefrogs that show very little morphological variation despite the existence of various names. The allocation of the specimens from Nagaland to a species name should be confirmed, but as no voucher specimens exist, we removed this species from the list.

The list of frogs from Nagaland now shows a total of 32 species which is almost three times the species of Chanda's (1994) list but probably much below the actual number of species. We yet cannot have any idea about the total number of species which should be much higher when compared to similar places in southeast Asia and Himalaya (see Ohler et al., 2002, Dubois, 2000).

\section{Acknowledgement}

Meren Ao gratefully acknowledges the financial support of Declining Amphibian Population Task Force (DAPTF) in the form of Seed grant.

\section{References}

Chanda, S.K. (1994). Anuran (Amphibia) fauna of Northeast India. Memoirs of Zoological Survey India 18: vi+143, 21 maps.

Chanda, S.K., I. Das and A. Dubois (2001). Catalogue of amphibian types in the collection of the Zoological Survey of India. Hamadryad 25(2): 100-128.

Dubois, A. (1992). Notes sur la classification des Ranidae (Amphibiens Anoures). Bulletin mens. Soc. linn. Lyon 61(10): 305-352.

Dubois, A. (2000). The influence of man on the distribution of amphibians in the Himalayas of Nepal: an example of critical evaluation of biogeographical data. In: Miehe, G. and Y. Zhang (Eds.). Environmental changes in high Adia. Marburger geogr. Schriften 135: 326-345.

Inger, R.F. (1999). Distribution of amphibians of southern Asia and adjacent islands, pp. 456-482. In: Duellman, W.E. (Ed.). Patterns of Distribution of Amphibians: A Global Perspective. John Hopkins University Press, Baltimore.

Kiyasetuo and M.K. Khare (1986). A new record of frog, Chirixalus vittatus (Boulenger,1887) from North Eastern Hills of India. Zoo. Orientalis 3(1-2):47-49.

Kiyasetuo (1986) Studies on survey of toads and frogs of Kohima, Nagaland and certain aspects of ecology and development of Rhacophorus leucomystax (Kuhl). Ph.D. Thesis. North Eastern Hill University, Shillong, Meghalaya, India.

Kiyasetuo and M.K. Khare (1986). A new genus of frog (Anura: Ranidae) from Nagaland at the North Eastern hills of India. Asian Journal of Experimental Science 1: 12-17.

Kiyasetuo and M.K. Khare (1987). A new record of Rhacophorus bisacculus Taylor, from north eastern hills of India. Journal of Assam Science Society 29(3): 16-19.

Ohler, A. and P.K. Mallick (2002). Rana (Hylarana sensu Dubois (1992) in India and the identity of Hylorana tytleri Theobald, 1868. Hamadryad 27(1): 57-65.

Ohler, A., S.R. Swan and J.C. Daltry (2002). A recent survey of the amphibian fauna of the Cardamom mountains, southwest Cambodia with descriptions of three new species. Raffles Bulletin of Zoology 50(2): 171-188. 